until about ten minutes later, nor did they do anything for the deceased. Another keeper named Leddy, however, arrived on the scene, and went for the doctor, and on the arrival of the latter about three minutes later he found Ward lying dead. Dr. Roantree, who afterwards made a post-mortem examination of the body of the deceased, certified that the cause of death was fatty degeneration of the heart, accelerated by acute alcoholic poisoning. Dr. Gilcriest, Acting Resident Medical Superintendent of the institution, after finding life extinct in the body of the deceased, questioned the keepers, with the res.It that he charged both of them with being drunk while on duty. Kelly admitted having taken three or four bottles of stout that evening, but Cullen denied it.

"Chief Attendant Feeney swore that Cullen's breath smelt of drink, but he had no other appearance of drink on that evening.

"The jury returned a verdict to the effect that the deceased died from alcoholic poisoning, and added a rider that they found the attendance and supervision in the institution bad."

The management of the Sligo Asylum called for some comment from us a few years ago when the Committee were anxious to reinstate in charge of the insane an attendant who had just served a period in jail for an assault on a patient. It is understood that that devoted and heroic public servant, for whom his kindly and appreciative Committee had such sympathy, would have complied with their generous desire and returned to exercise his gentle sway over the patients in the Sligo Asylum, had it not been for the untoward circumstance that he was "wanted" for some other offence by those oppressive guardians of public order, the Royal Irish Constabulary, and found it judicious to retire into private life for a time. That whiskey should get into an Irish asylum at Christmas time does not surprise us, but we must admire the ingenuity of employing a patient, if this were done, as purveyor of drink. Death of an asylum patient by acute alcoholic poisoning is startlingly original-absolutely unique in fact. It quite puts in the shade the mere old-fashioned exploits of beating patients, breaking their ribs, noses, etc. Perhaps it falls under the term so often referred to in modern Irish life - Killing with Kindness."

\title{
MONAGHAN ASYLUM COMMITTEE AND THE MEDICAL
} SUPERINTENDENT.

According to a very detailed report which appears in the Anglo-Celt newspaper of Cavan, under date December I7th, 1904, the proceedings at the monthly meeting of the asylum for the counties of Monaghan and Cavan at Monaghan, held on the 15th December, must have been of that lively, original, and truly Hibernian character which the mere Saxon never can understand. It would appear that General Clifford, one of the Committee, moved the following motion :- "That the Lord Lieutenant be requested to direct that Dr. Taylor be subjected to expert medical examination with a view to ascertaining whether, in the present state of his eyesight, he is capable of performing his duties as Resident Medical Superintende..t."

Dr. Taylor is reported to have thereupon requested to be heard through his solicitor. The latter gentleman, not being familiar, as it would seem, with the methods of Irish asylum committees, did not content himself with pointing out that the proposed action of the Committee was ultra vires and that the Lord Lieutenant was unlikely to venture on a course which the Czar would be afraid and the Sultan ashamed of, but went on to endeavour to awaken the conscience of the Committee to what he called the "persistent persecution" to which Dr. Taylor has been subjected. He said that the object of the motion was to worry and annoy Dr. Taylor in the hope that he would consequently hand in his resignation and make a vacancy. As might have been expected, this kind of talk merely led to further recrimination, chiefly interesting as showing the methods which the Irish adopt in dealing with public servants. Attempting to justify his resolution by stating that Dr. Taylor's eyesight was too bad to enable that officer to discharge 
his duties, General Clifford went on :- "I am perfectly certain from what I have seen that Dr. Taylor cannot take the temperature of a patient no more than he can fly. From my own personal observation it appears that Dr. Taylor is unable to recognise different gentlemen coming into this institution. I say that it is a saving to the ratepayers to have Dr. Taylor in a position to discharge his duties properly, but in my opinion he is physically incapable of discharging these duties. I would move that we have experi opinion as to his eyesight."

"When pigs begin to fly," as they say in Ireland, General Clifford will probably be a good judge of the duties of a medical superintendent, and have some valuable original opinions as to temperzture taking. We can quite believe that Dr. Taylor may experience some difficulty in recognising a gentleman among some of those who come into the institution, but surely this cannot be a disqualification for a post connected with the Monaghan and Cavan Asylum.

Mr. Mullen, we are told, moved a negative. He said-" Because Dr. Taylor is doing his duty fearlessly and conscientiously, as he has done up to the present, General Clifford comes forward and demands that someone else should take his place. I move now that we do not receive General Clifford's motion."

The Most Rev. Dr. Owens, Roman Catholic Bishop of Clogher, supported Mr. Mullen. In a very generous and handsome speech, he upheld the character and capacity of the unfortunate doctor against the enemies who were baiting him. Speaking with the intimate personal knowledge which his position gave him, as well as the fact that he lives close to the asylum, has a right of way through its grounds, and has been longer and more closely associated with it than any other member of the Committee, he testified to the excellence of Dr. Taylor's services, and said he thought it would be very hard to get a more capable official. He had one quarrel with Dr. Taylor, and as to that he said-"I reproached him for not taking the proper steps to put an end to the abusive charges that were being made against him and have damages obtained against the gentlemen who made the accusations." He went on to say that he regarded the present motion as libellous, and that if he were the medical superintendent he would take an action against its proposer for 610,000 or so. It would appear to us that the peculiar form which the resolution took was probably slyly arranged to dodge the law of libel, however. Casually the Bishop observed that the matter was before the Committee on a previous occasion and was defeated by a majority.

The scrimmage that followed on the just and kindly remarks of the Bishop would have little interest for our readers. It suffices to note three small items. First, it would appear that the Committee some time ago gave an order that the Medical Superintendent should take his turn with his assistants of visiting the wards at night. Can it be that the poor gentleman suffers from nyctalopia, and that this order was given in order to reveal his weakness? Secondly, it was suggested that the night attendant should be questioned as to Dr. Taylor's visits at nights. It is impossible to read an Irish story without observing how large a figure the spy and informer cuts in the narrative. We can quite imagine his being the leading spirit in an Irish asylum. Thirdly, a strong motive in some for voting against the motion was that an election of Committee is coming on, and that it would be wiser to leave the question of Dr. Taylor's vision to people who knew presumably nothing about it rather than to those who did. Why this notion ruled we are not sufficiently versed in local politics to tell, but the insinuation of suine personal reason pro or con was very plain.

The motion of General Clifford was eventually negatived by six votes to five.

\section{THE OPENING OF THE NEW CHAPEL AT JAMES MURRAY'S ROYAL ASYLUM AT PERTH.}

The following extracts are from the pages of Excelsior:

"An important and impressive ceremony was witnessed at Murray's Royal Asylum on Thursday, September 29th, 1904, when the new chapel was solemnly dedicated, and the new villas adjoining were formally opened. The function was

I.I. 